\title{
Vrijeme traiania zavarivanja kao važan čimbenik zavarivanja bukovine
}

\section{Welding Time as an Important Factor of Beech Welding}

\author{
Original scientific paper • Izvorni znanstveni rad \\ Received-prispjelo: 15. 12. 2010. \\ Accepted-prihvaćeno: 27. 4. 2011. \\ UDK: $630 * 824 ; 674.028 .1$ \\ doi:10.5552/drind.2011.1041
}

\begin{abstract}
SAŽETAK • Spajanje drva klinovima bez ikakva lijepljenja i zavarivanja bilo je korišteno stoljećima. Ako ti klinovi (u ovom istraživanju moždanici) rotiraju prilikom spajanja s podlogom (u kontroliranim uvjetima), uz određene parametre nastaje čvrsti spoj znatne čvrstoće. Zavarivanje drva je proces u kojemu se zbivaju kemijsko-fizikalne reakcije, zbog trenja nastaje toplina koja tali i omekšava strukturu drva, a hlađenjem tako nastale taline dobiva se čvrsti spoj. U radu su prikazane dosadašnje svjetske spoznaje, ali i rezultati vlastitih istraživanja utjecaja trajanja procesa zavarivanja na izvlačnu silu između bukova moždanika i podloge. Najbolje rezultate izvlačne sile (4 994 N) imali su spojevi kod kojih je proces zavarivanja moždanika trajao od 0,56 do 0,9s (po svakom okretaju moždanika pomak je bio 1,41 do 0,88 mm), a najmanja izvlačna silu (2 $869 \mathrm{~N})$ zabilježena je pri trajanju zavarivanja od 1,81 od 2,61 s. Prosječna izvlačna sila spoja lijepljenih spiralno nažlijebljenih moždanika iznosila je $5028 \mathrm{~N}$.
\end{abstract}

Ključne riječi: zavarivanje masivnog drva, vrijeme zavarivanja, čvrstoća zavarenog spoja, moždanici, izvlačna sila

\begin{abstract}
Bonding of wood by virtue of wedge, without any adhesives and welding, has been done for centuries. If such wedge (in this research wood dowels) are rotated during the bonding with the surface (in controlled conditions) at certain parameters, a firm joint is formed. Welding of wood is a process where chemical and physical reactions take place, heat is formed during the friction that melts and softens the structure of wood, and a firm joint is formed by cooling of the melt. The paper shows world findings so far, as well as the results of our own research of the influence of welding process on the dowel embedded force between the beech wood dowel and the beech surface. The joints with the best results concerning the dowel embedded force (4994 N) were the joints where the process of impressing wood dowels lasted from 0.56 to $0.9 \mathrm{~s}$ (with each turn of the wood dowel, the movement was 1.41 to $0.88 \mathrm{~mm})$ and the lowest dowel embedded force $(2869 \mathrm{~N})$ was recorded when the duration of the impressing lasted from 1.81 to $2.61 \mathrm{~s}$. The average embedded force of glued spirally grooved dowels amounts to $5028 \mathrm{~N}$.
\end{abstract}

Key words: welding of beech, welding time, strength of the welded joint, dowels, embedded force

\footnotetext{
${ }^{1}$ Autori su viši asistent i redoviti profesori Šumarskog fakulteta Sveučilišta u Zagrebu, Zagreb, Republika Hrvatska.

Authors are senior assistant and professors at Faculty of Forestry, University of Zagreb, Croatia.
} 


\section{UVOD}

\section{INTRODUCTION}

Dvije najčešće primjenjivane metode zavarivanja masivnog drva i drvnih ploča jesu zavarivanje uz pomoć vibracije i zavarivanje uz pomoć rotacije. Vibracijsko zavarivanje može se podijeliti ovisno o smjeru vibriranja na linearno i kružno. Pri rotacijskom zavarivanju podloga (elementi) miruje, a moždanik (drveni čep) rotira uz pomak u smjeru svoje uzdužne osi. Obilježje obiju metoda jest trenje na kontaktnim površinama. Zbog trenja na kontaktnim površinama stvara se toplina koja „omekša i rastali” strukturu drva (drvne polioze i lignin), a vlakanca drva međusobno se isprepleću. Pri hlađenju zbiva se kemijsko-fizički proces (struktura drva otvrdnjava) povezivanja spojenih elemenata te nastaje čvrsto zavareni spoj.

Od 2000 IBOIS (Swiss Federal Institute of Technology Lausanne) razvija i istražuje metodu spajanja drva uz pomoć trenja (zavarivanje drva), bez dodavanja ikakvih vezivnih sredstava (Gliniorz i Natterer, 2000; Gliniorz i dr., 2001). Objavili su kako je zavarivanje drva za drvo uz pomoć trenja inovativni proces s velikim potencijalom za buduća istraživana.

Utjecaj trajanja procesa zavarivanja moždanika u toplinski tretiranu i netretiranu grabovinu istraživali su Župčić i dr. (2009.), kao i u bukovinu (Župčić i dr., 2009.). Iz rezultata istraživanja vidljivo je smanjenje izvlačne sile s produljenjem trajanja procesa zavarivanja.

Zador pri zavarivanju moždanika jedan je od vrlo bitnih čimbenika zavarivanja te ima znatan utjecaj na čvrstoću spoja (Pizzi i dr., 2003; Ganne-Chedeville i dr., 2005). Optimalni zador pri rotacijskom zavarivanju moždanika (prema spomenutim autorima) iznosi 2 $\mathrm{mm}$, pa je zbog toga u ovim istraživanju korišten zador od $2 \mathrm{~mm}$. Najveća izvlačna sila postignuta je kada je bukov nažljeblijeni moždanik zavaren u bukovu podlogu, u provrt od $8 \mathrm{~mm}$, frekvencijom vrtnje od 1200 okr./min. Dubina zavarivanja iznosila je $12 \mathrm{~mm}$, a prosječna izvlačna sila 883 N (Pizzi i dr., 2004). Prema provedenim istraživanjima (Župčić i dr., 2010), vidljivo je da izvlačna sila postiže maksimalne iznose pri zadoru od 2 do $2,5 \mathrm{~mm}$, pa su to ujedno i optimalni zadori za rotacijsko zavarivanje nažlijebljenih moždanika (frekvencija vrtnje $1520 \mathrm{okr} . / \mathrm{min}$, dubina zavarivanja $20 \mathrm{~mm}$ ). Kada se zadori povećavaju ili smanjuju u odnosu prema optimalnima statistički se značajnije smanjuju izvlačne sile odnosno čvrstoća spoja.

Veza između temperature, vremena trajanja trenja i toplinskih strujanja pri rotacijskom zavarivanju moždanika (drvenog čepa) visokom frekvencijom vrtnje može se pratiti uz pomoć matematičkog modela prijenosa topline (Zoulalian i Pizzi, 2007). Temperatura kontaktnih površina (sljubnica) može se odrediti kao funkcija vremena i trajanja trenja (zavarivanja) prema formuli:

gdje je:

$$
T_{0}=T_{\mathrm{i}}+\frac{2 \cdot \beta \cdot \mu \cdot \tau \cdot \sqrt{\alpha}}{h \cdot \sqrt{\pi}} \cdot \sqrt{t}
$$

$T_{0}$ - temperatura zavarivanja (sljubnica)

$T_{\mathrm{i}}$ - početna temperatura drva $t$ - vrijeme zavarivanja

$\tau$ - trenje pri pritisku

$\mu$ - frekvencija vrtnje ili vibracije

$\beta$-mehanička energija trenja pretvorena u toplinsku energiju

$h$ - toplinska vodljivost

$\alpha$-difuznost drva.

Za rotacijsko i linearno zavarivanje vrijednost $\beta$ jednaka je $0,080 \pm 0,01$. Prema rezultatima istraživanja (za rotacijsko zavarivanje), optimalna temperatura zavarivanja iznosi oko $180^{\circ} \mathrm{C}\left(183^{\circ} \mathrm{C}\right)$. S prestankom djelovanja trenja ta se temperatura naglo smanjuje. Za vibracijsko zavarivanje drva raspodjelu temperature zavarivanja istraživala je Ganne-Chedeville i dr. (2008). Od početka procesa zavarivanja do 5,5 s trajanja zavarivanja događa se naglo povećanje temperature od 25 na $250^{\circ} \mathrm{C}$. Od 5,5 do 10,5 s temperatura se stabilizira na približno $250{ }^{\circ} \mathrm{C}$, krivulja prikazuje nekoliko skokova, ali nema znatnije promjene. Nakon 10,5 s uređaj za vibracijsko zavarivanje se zaustavlja, vibracije prestaju i temperatura se smanjuje jer nema trenja (koje je uzrok nastajanja topline).

Važan čimbenik koji utječe na čvrstoću spoja odnosno izvlačnu silu jest frekvencija vrtnje. Ona je usko povezana s pomakom moždanika u smjeru uzdužne osi moždanika za vrijeme rotacije. Najveću izvlačnu silu imali su moždanici zavareni frekvencijom vrtnje 1500 okr./min, a trajanje zavarivanja iznosilo je $4 \mathrm{~s}$ (Leban i dr., 2008). Najslabiji rezultati postignuti su s moždanicima zavarenim frekvencijom vrtnje $6500 \mathrm{okr}$./min, u vremenu 2,3 s. U ovom je istraživanju korišteno vrijeme zavarivanja od 2 do 4 s, ovisno o frekvenciji vrtnje. Frekvencija vrtnje moždanika važan je čimbenik zavarivanja (Župčić, 2010). Utječe na izvlačnu silu i na čvrstoću spoja na način da je zabilježeno povećanje izvlačne sile, ali i čvrstoće (s obzirom na to da površina spoja nije promijenjena) s njezinim povećanjem od 865 okr./ min do $1720 \mathrm{okr} . / \mathrm{min}$. Utjecaj frekvencije vrtnje na izvlačnu silu može se smanjiti ako se poštuje pomak moždanika po okretaju, odnosno ako se trajanje zavarivanja prilagodi frekvenciji vrtnje.

Cilj rada bio je utvrditi utjecaj trajanja procesa zavarivanja na izvlačnu silu i čvrstoću rotacijski zavarenih moždanika okomito na smjer vlakanaca drva (radijalno-tangentna tekstura).

\section{MATERIJALI I METODE \\ 2 MATERIALS AND METHODS}

Istraživanja utjecaja trajanja procesa zavarivanja moždanika u podlogu od bukovine provedena su na Šumarskom fakultetu Sveučilišta u Zagrebu. Bukovi nažlijebljeni moždanici zavarivani su u podlogu od bukovine okomito na smjer drvnih vlakanaca (radijalno-tangentna tekstura).

\subsection{Ispitni uzorci}

2.1 Test samples

Za zavarivanje moždanika metodom rotacije upotrijebljeni su uzorci dimenzija 200 x 30 x 30 mm (sl. 1). 
...... Župčić, Bogner, Grbac: Vrijeme trajanja zavarivanja kao važan čimbenik zavarivanja...
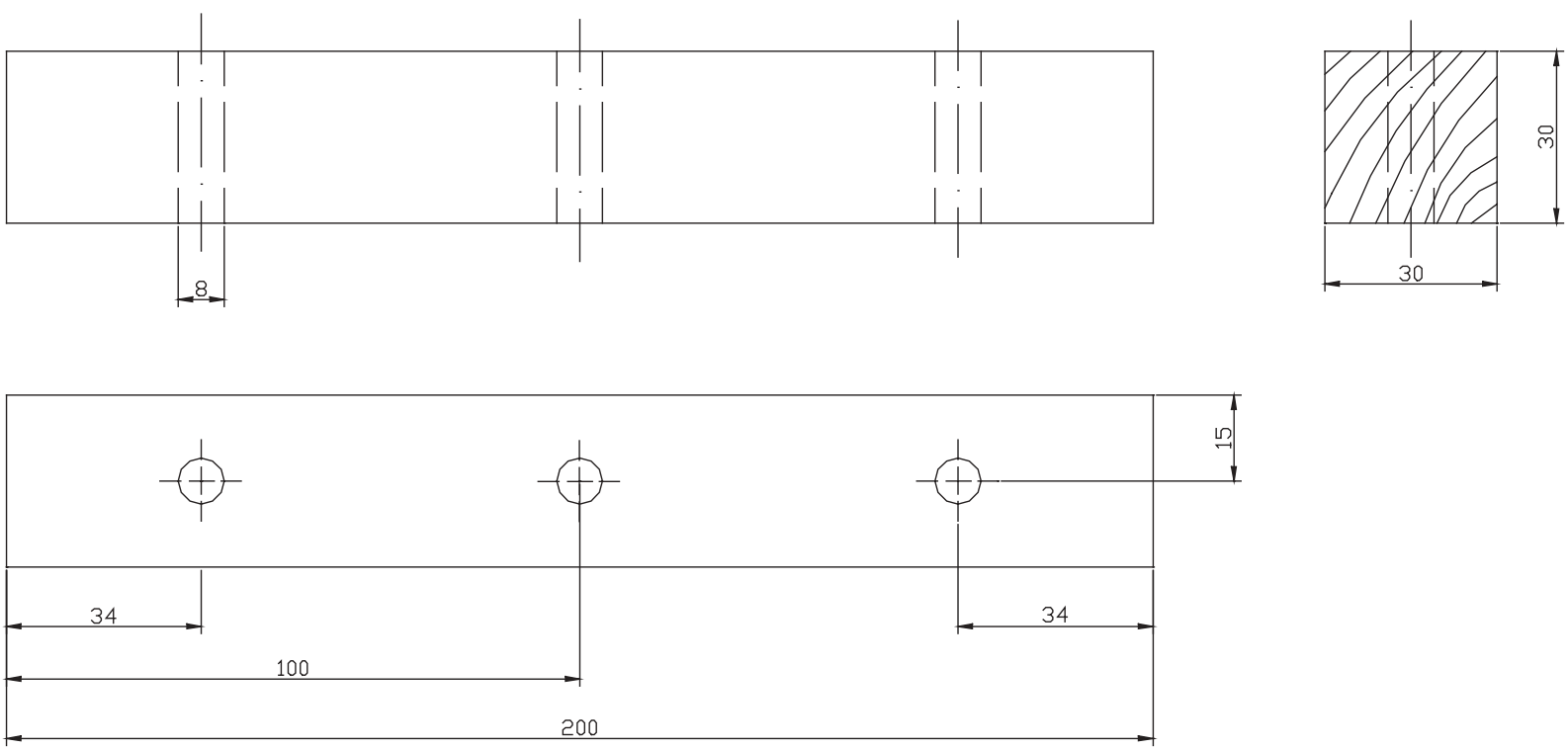

Slika 1. Ispitni uzorak za određivanje izvlačne sile

Figure 1 Test sample for determination of the embedded force

Na svakom uzorku izbušene su po tri rupe (34 mm od oba kraja uzorka te u sredini uzorka), svrdlom promjera $8,1 \mathrm{~mm}$. Promjer rupe bio je od 0,06 do $0,1 \mathrm{~mm}$ manji od promjera svrdla, na što su utjecale elastične deformacije drva za vrijeme bušenja rupe. Prosječni promjer moždanika (mjeren na vrhu nažljebljenja unakrsno) iznosio je $10,04 \mathrm{~mm}$, pa je prosječni zador pri zavarivanju iznosio 2,02 mm. Moždanici su bili ravno nažljeblijeni, duljine $120 \mathrm{~mm}$, a zavarivani su na dubinu od $20 \mathrm{~mm}$ frekvencijom vrtnje od $1520 \mathrm{okr}$./min. Od ukupno 130 zavarenih moždanika, 120 ih je uključeno u istraživanje, dok je u 10 uzoraka za vrijeme zavarivanja raspucala podloga ili se dogodio lom moždanika pri ispitivanju izvlačne sile pa nisu uključeni u daljnja istraživanja.

Kontrolni su uzorci lijepljeni poliuretanskim (PU) ljepilom (komercijalnog naziva TIMBER MAX) Bison International, koje je prema deklaraciji otporno na slatku i slanu vodu. Korištena su dva tipa moždanika: jedan je bio spiralno nažlijebljen, srednjeg promjera $10,35 \mathrm{~mm}$, a drugi tip bili su ravno nažlijebljeni moždanici srednjeg promjera $10,05 \mathrm{~mm}$. Promjer rupe bio je od 0,06 do 0,1 mm manji od promjera svrdla. Uzorci su bili jednakih dimenzija kao i za zavarivanje, jedina je razlika bio promjer svrdla od $10 \mathrm{~mm}$. Za svaki tip moždanika izrađeno je po pet uzoraka s tri rupe u svakome (ukupno $14+15$ ). Na jednom uzorku sa spiralno nažlijebljenim moždanikom nastao je lom po žici drva izvan spoja, pa nije korišten u daljnjim razmatranjima. Prosječni zador pri lijepljenju ravno nažlijebljenih moždanika iznosio je $0,13 \mathrm{~mm}$, a u spiralno nažlijebljenih zador je iznosio $0,42 \mathrm{~mm}$.

Nakon zavarivanja i lijepljenja uzorci su kondicionirani u određenim klimatskim uvjetima (temperatura $23{ }^{\circ} \mathrm{C}$, relativna vlaga zraka $50 \%$ ) tijekom osam dana, nakon čega je provedeno ispitivanje izvlačne sile.

\subsection{Određivanje sadržaja vode i gustoće}

\subsection{Determination of moisture content and density}

Prije zavarivanja uzorci su oko šest mjeseci držani u određenim klimatskim uvjetima (temperatura

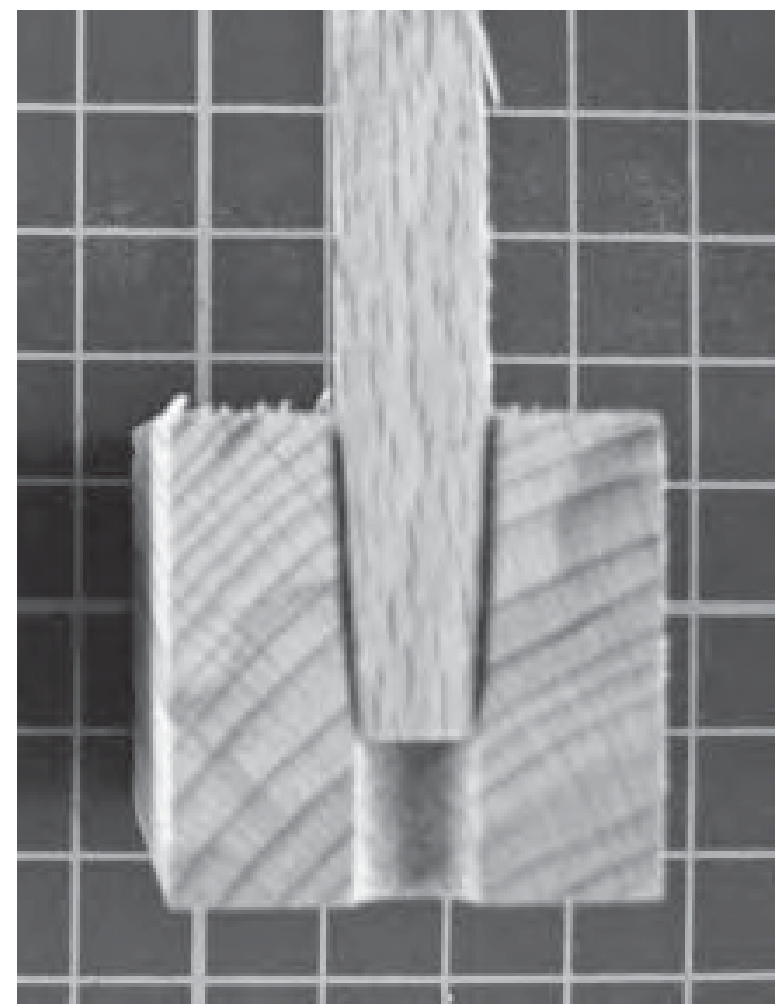

Slika 2. Presjek zavarenog moždanika

Figure 2 Cross section of welded dowels

$23{ }^{\circ} \mathrm{C}$, relativna vlaga zraka $50 \%$ ), ali sadržaj vode u drvu nije mjeren. Nakon završetka ispitivanja izvlačne sile svaki se uzorak određivao sadržaj vode. Na udaljenosti $50 \mathrm{~mm}$ od kraja uzorka ispiljena je po jedna proba, kojima je odmah određena masa (vaganjem) te su stavljeni u sušionik. Svi uzorci (probe) osušeni su na 0 $\%$ sadržaja vode $\left(103 \pm 2{ }^{\circ} \mathrm{C}\right)$ do konstantne mase. Sadržaj vode određivao se prema HRN ISO 3130 : 1999. (hrvatska norma za određivanje sadržaja vode za ispitivanje fizikalnih i mehaničkih svojstava drva). Prosječan sadržaj vode iznosio je 7,1 \% (min. 6,5\%, maks. 7,7\%). 
Tablica 1. Opis korištenih oznaka

Table 1 Description of used designations

\begin{tabular}{|c|c|}
\hline Oznaka / Code & Opis / Description \\
\hline$(0,56-0,9)$ & $\begin{array}{l}\text { vremenski interval zavarivanja } \\
\text { Turnaround time of welding }\end{array}$ \\
\hline$(0,91-1,2)$ & $\begin{array}{l}\text { vremenski interval zavarivanja } \\
\text { Turnaround time of welding }\end{array}$ \\
\hline$(1,21-1,5)$ & $\begin{array}{l}\text { vremenski interval zavarivanja } \\
\text { Turnaround time of welding }\end{array}$ \\
\hline$(1,51-1,8)$ & $\begin{array}{l}\text { vremenski interval zavarivanja } \\
\text { Turnaround time of welding }\end{array}$ \\
\hline$(1,81-2,61)$ & $\begin{array}{l}\text { vremenski interval zavarivanja } \\
\text { Turnaround time of welding }\end{array}$ \\
\hline MLSN & $\begin{array}{l}\text { lijepljeni spiralno nažlijebljeni moždanik } \\
\text { (kontrolni uzorak) } \\
\text { Glued spirally grooved dowels (control } \\
\text { sample) }\end{array}$ \\
\hline MLRN & $\begin{array}{l}\text { lijepljeni ravno nažlijebljeni moždanik } \\
\text { (kontrolni uzorak) } \\
\text { Glued straight grooves dowels (control } \\
\text { sample) }\end{array}$ \\
\hline
\end{tabular}

Nakon što je određen sadržaj vode u drvu, istim je probama određivana gustoća drva prema HRN ISO 3131 : 1999. (hrvatska norma za određivanje gustoće drva za ispitivanje fizikalnih i mehaničkih svojstava drva). Prosječna gustoća $\left(\rho_{0}\right)$ iznosila je $0,69 \mathrm{~g} / \mathrm{cm}^{3}$ (min. $0,61 \mathrm{~g} / \mathrm{cm}^{3}$, maks. $0,78 \mathrm{~g} / \mathrm{cm}^{3}$ ).

\subsection{Metoda ispitivanja \\ 2.3 Testing method}

Ispitivanje izrađenih (zavarenih) uzoraka provedeno je na Šumarskom fakultetu Sveučilišta u Zagrebu (Zavod za znanost o drvu), na univerzalnoj kidalici. Aksijalni pomak (u smjeru uzdužne osi moždanika) za vrijeme ispitivanja iznosio je $5 \mathrm{~mm} / \mathrm{min}$. Uz pomoć dinamometra spojenog preko računala obavljena su mjerenja sile i pomaka, pa su sve vrijednosti točno i precizno određene. Sva su ispitivanja rađena najmanje sedam dana nakon zavarivanja ili lijepljenja (kondicioniranje uzoraka).

S obzirom na to da je riječ o specifičnom ispitivanju, konstruiran je i napravljen poseban prihvat za moždanike kako bi se spriječilo proklizavanje uzorka (moždanika) za vrijeme ispitivanja. Alat je omogućivao da os simetrale ispitnog uzorka bude u smjeru osi simetrale kidalice po kojoj djeluje sila.

\section{REZULTATI I DISKUSIJA}

\section{RESULTS AND DISCUSSION}

Da bi se moglo ostvariti trenje između površina u kontaktu (pri rotacijskom zavarivanju), potreban je određeni zador (razlika između promjera rupe i moždanika) i frekvencija vrtnje moždanika u određenome vremenskom trajanju. Frekvencija vrtnje moždanika i trajanje procesa zavarivanja međusobno su povezani i ovise jedno o drugome. Posljedica trenja je pojava topline na kontaktnim površinama (sljubnicama) i smanjenje volumena moždanika te povećanja volumena rupe. Toplina površinski omekša i rastali strukturu drva na mjestu dodira i nastaje talina čijim se hlađenjem do- biva čvrsti spoj. Smanjenje volumena moždanika i povećanje volumena rupe ima dva učinka: urušavaju se stanične stijenke (zatvara se lumen stanica) i povećava površinska gustoća sljubnice, koja obično iznosi do 1,4 $\mathrm{g} / \mathrm{cm}^{3}$ (Pizzi i dr., 2004). Drugi dio volumena nestaje zbog abrazivnog djelovanja trenja i otjecanja taline iz zone sljubnice. Upravo u tim procesima zador, frekvencija vrtnje moždanika i trajanje procesa zavarivanja imaju važnu ulogu. Zador utječe na raspoloživi volumen drva potreban za stvaranje spoja. Pri prevelikim zadorima i frekvencijama vrtnje veće je mehaničko trošenje drva (mehanička destrukcija vlakanaca) i veća je toplina zbog čega se smanjuje čvrstoća spoja. Uz povišenu frekvenciju vrtnje i produljeno vrijeme trajanja zavarivanja dobivaju se spojevi male čvrstoće. U tom je slučaju površina sljuba odnosno linija zavarivanja zaglađena i na toj se površini ne ostvaruje zavarivanje (sl. 3).

Utjecaj vremena zavarivanja za radijalno-tangentni presjek (smjer zavarivanja okomit na vlakanca drva) na izvlačnu silu u nažlijebljenih moždanika ispitivan je u vremenskom intervalu od $0,56 \mathrm{~s}$ do 2,61 s (prosječno 1,213 s). Tih 2,05 sekundi podijeljeno je na pet intervala. Svaki je interval trajao približno tri desetinke sekunde osim zadnjeg petoga, koji je trajao sedam desetinki sekunde (od 1,81 do 2,61 s). U vremenskom intervalu od 0,56 do 0,9 s pomak moždanika iznosio je od 1,41 do $0,88 \mathrm{~mm}$ po okretaju, a u najduljem intervalu zavarivanja $(1,81$ do $2,61 \mathrm{~s})$ taj je pomak iznosio od 0,43 do $0,30 \mathrm{~mm}$ po okretaju, što je gotovo 4,7 puta manje. Iz grafičkog prikaza na slici 4. i 5. vidljivo je postupno smanjenje izvlačne sile s povećanjem trajanja procesa zavarivanja. Najbolji rezultati postignuti su u prvom intervalu zavarivanja, u trajanju od 0,56 do $0,9 \mathrm{~s}$, pri čemu je prosječna izvlačna sila iznosila 4994 N. Prosječna izvlačna sila za interval od 1,81 do 2,61 s iznosila je $2869 \mathrm{~N}$ što je gotovo 1,7 puta manje nego u intervalu od 0,56 do $0,9 \mathrm{~s}$.

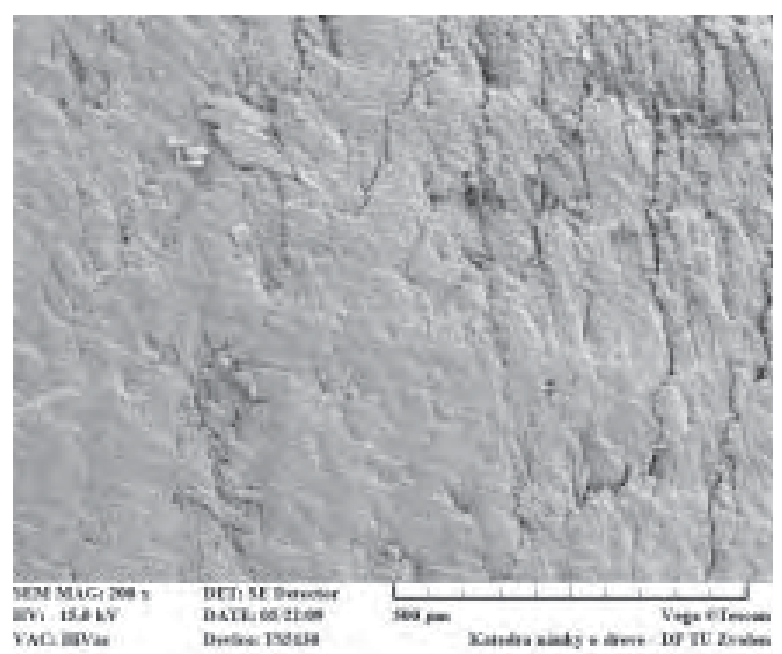

Slika 3. Površina moždanika s dna spoja (vrha moždanika): glatka površina loma upućuje na velik udio lignina i lom po sloju lignina. Snopovi vlakanaca usmjereni su i zaglađeni u smjeru rotacije (Župčić, 2010).

Figure 3 Dowel surface from the bottom joint (top of the dowel), smooth surface of refraction shows a large portion of lignin and refraction according to the lignin layer. Wood fibres are lined up in spin direction (Župčić, 2010.). 
Tablica 2. Deskriptivna statistika izvlačne sile u ovisnosti o vremenu zavarivanja Table 2 Descriptive statistics of embedded force in correlation with welding time

\begin{tabular}{|l|c|c|c|c|c|}
\hline $\begin{array}{l}\text { Vrijeme } \\
\text { zavarivanja } \\
\text { Welding time }\end{array}$ & $\begin{array}{c}\text { Aritmetička sredina } \\
\text { izvlačne sila } \\
\text { Embedded force } \\
\text { Mean }\end{array}$ & $\begin{array}{c}\text { Broj uzoraka } \\
\text { Number of } \\
\text { samples }\end{array}$ & $\begin{array}{c}\text { Standardna devija- } \\
\text { cija izvlačne sile } \\
\text { Embedded force Std. } \\
\text { Dev. } \\
\mathrm{N}\end{array}$ & $\begin{array}{c}\text { Minimalna } \\
\text { izvlačna sila } \\
\text { Embedded force } \\
\text { Minimum } \\
\mathrm{N}\end{array}$ & $\begin{array}{c}\text { Maksimalna } \\
\text { izvlačna sila } \\
\text { Embedded force } \\
\text { Maximum } \\
\mathrm{N}\end{array}$ \\
\hline$(0,56-0,9)$ & 4994,0 & 30 & 562,7 & 4040 & 5940 \\
\hline$(091-1,2)$ & 4634,4 & 39 & 615,5 & 3500 & 5720 \\
\hline$(1,21-1,5)$ & 4470,3 & 31 & 736,0 & 2640 & 5840 \\
\hline$(1,51-1,8)$ & 3800,0 & 7 & 818,2 & 2700 & 5320 \\
\hline$(1,81-2,61)$ & 2869,2 & 13 & 742,5 & 1930 & 4360 \\
\hline MLSN & 5028,6 & 14 & 582,8 & 4020 & 6000 \\
\hline MLRN & 3198,7 & 15 & 503,9 & 2560 & 4000 \\
\hline Sve grupe & 4371,9 & 149 & 942,1 & 1930 & 6000 \\
\hline All groups & & & & & \\
\hline
\end{tabular}

Vrijeme zavarivanja mnogo manje od 0,5 s nije moguće postići zbog lomova u podlozi i moždaniku. Pukotine u podlozi pojavljuju se zbog sile koja djeluje na obod rupe što je uzrokuje moždanik zbog zavaravanja. Ako je smjer zavarivanja radijalni, pukotine se šire po drvnim tracima, dok radijalno-tangentna tekstura smanjuje pojavu pukotina. Dimenzija podloge svakako utječe na pojavu pukotina za vrijeme zavarivanja. Ako je vrijeme zavarivanja kratko, dolazi do loma moždanika zbog momenta koji djeluje na moždaniku u obliku torzije.

Između prva tri intervala zavarivanja (sl. 4) ne postoji statistički značajna razlika, pa proizlazi kako je prihvatljivo vrijeme zavarivanja ograničiti do 1,5 s. Pri zavarivanju od 1,5 s moždanik napravi 38 okretaja ili pomak po okretaju od $0,53 \mathrm{~mm}$. Između lijepljenja spiralno nažlijebljenog moždanika i zavarivanja (prva tri intervala zavarivanja) također ne postoji statistički značajna razlika. Usporedbom zavarivanja moždanika u vremenu od 1,51 do 2,61 s i lijepljenja ravno nažlijebljenog moždanika ne postoji statistički značajna razlika. Među ostalim kombinacijama usporedbe postoji statistički značajna razlika. Usporedba zavarivanja i lijepljenja moždanika u podlogu samo uz pomoć izvlačne sile nije u potpunosti opravdana s obzirom na to da se zavarivanjem moždaniku smanjuje površina. Sa znanstvenoga gledišta mnogo je primjerenije uspoređivati zavareni i lijepljeni spoj prema čvrstoći. Prosječna površina ravno nažlijebljenog moždanika zavarenoga na dubinu od $20 \mathrm{~mm}$ iznosi 560,24 mm², a moždanika lijepljenog na jednaku dubinu površina je veća i iznosi $668,06 \mathrm{~mm}^{2}$. Površina zavarenog moždanika je oko 16 \% manja u usporedbi sa zalijepljenim moždanikom, a kako je čvrstoća omjer sile po jedinici površine, proizlazi da za iste vrijednosti izvlačne sile čvrstoća spoja raste u korist zavarivanja. Prosječna čvrstoća zavare- nog moždanika za interval od 0,56 do 0,9 iznosi 9,46 $\mathrm{N} / \mathrm{mm}^{2}$, a čvrstoća ravno nažlijebljenog lijepljenog moždanika iznosi 4,79 N/mm².

Prosječna izvlačna sila lijepljenih spiralno nažlijebljenih moždanika iznosi $5029 \mathrm{~N}$ pri zadoru od 0,42 mm. Ako je taj zador $0,13 \mathrm{~mm}$ i moždanici su ravno nažlijebljeni, prosječna izvlačna sila moždanika iznosi 3199 N. Oblik nažljebljenja i zador utječu na veličinu izvlačne sile. Zador od $0,13 \mathrm{~mm}$ svakako je premali i statistički značajno utječe na izvlačnu silu. Prema ovom istraživanju, optimalno je pri lijepljenju koristiti zador od 0,42 mm i spiralno nažljebljenje moždanika. Cilj rada nije bio definirati optimalni zador i tip moždanika pri lijepljenju već samo usporediti izvlačne sile lijepljenih komercijalnih moždanika u podlogu, na dubinu od $20 \mathrm{~mm}$.

Utjecaj vremena zavarivanja na izvlačnu silu (za ravno nažlijebljeni moždanik zavaren okomito na vlakanca u radijalno-tangentnom smjeru) u vremenskom intervalu od 0,56 s do 2,61 s može su promatrati uz pomoć logaritamske krivulje $(y=4668,9-3920,0$. $\log 10(x))$. Bilo je pokušaja prikazivanja rezultata istraživanja i uz pomoć drugih krivulja, ali se logaritamska pokazala najboljom. Logaritamska krivulja dobro opisuje os x jer se postupno primiče osi s povećanjem vremena zavarivanja. Budući da je najkraće vrijeme zavarivanja iznosilo $0,56 \mathrm{~s}$, nije poznato što se događa s krivuljom u vremenu zavarivanja manjemu od 0,56 s. Može se pretpostaviti da u vremenu manjemu od 0,5 s izvlačna sila smanjuje jer se u tako kratkom vremenu ne može dobro formirati talina kojom se postiže zavarivanje. Izvlačna sila kretala se u rasponu od maksimalnih $5940 \mathrm{~N}$ do minimalnih $1930 \mathrm{~N}$, što je tri puta manje. Prema korelacijskom koeficijentu $(\mathrm{r}=$ 0,726) proizlazi da je riječ o znatnoj povezanosti uspoređivanih podataka.

Tablica 3. Deskriptivna statistika utjecaja vremena zavarivanja Table 3 Descriptive statistics of impact of welding time

\begin{tabular}{|l|c|c|c|c|}
\hline Varijabla & $\begin{array}{c}\text { Aritmetička } \\
\text { Sredina } \\
\text { Mean }\end{array}$ & $\begin{array}{c}\text { Standardna } \\
\text { devijacija } \\
\text { Std. Dev. }\end{array}$ & $\begin{array}{c}\text { Minimum } \\
\text { Minimum }\end{array}$ & $\begin{array}{c}\text { Maksimum } \\
\text { Maximum }\end{array}$ \\
\hline izvlačna sila, N / Embedded force, $N$ & 4442,0 & 898,7 & 1930,0 & 5940,0 \\
\hline vrijeme zavarivanja, s / Welding time, $s$ & 1,21 & 0,44 & 0,56 & 2,61 \\
\hline
\end{tabular}




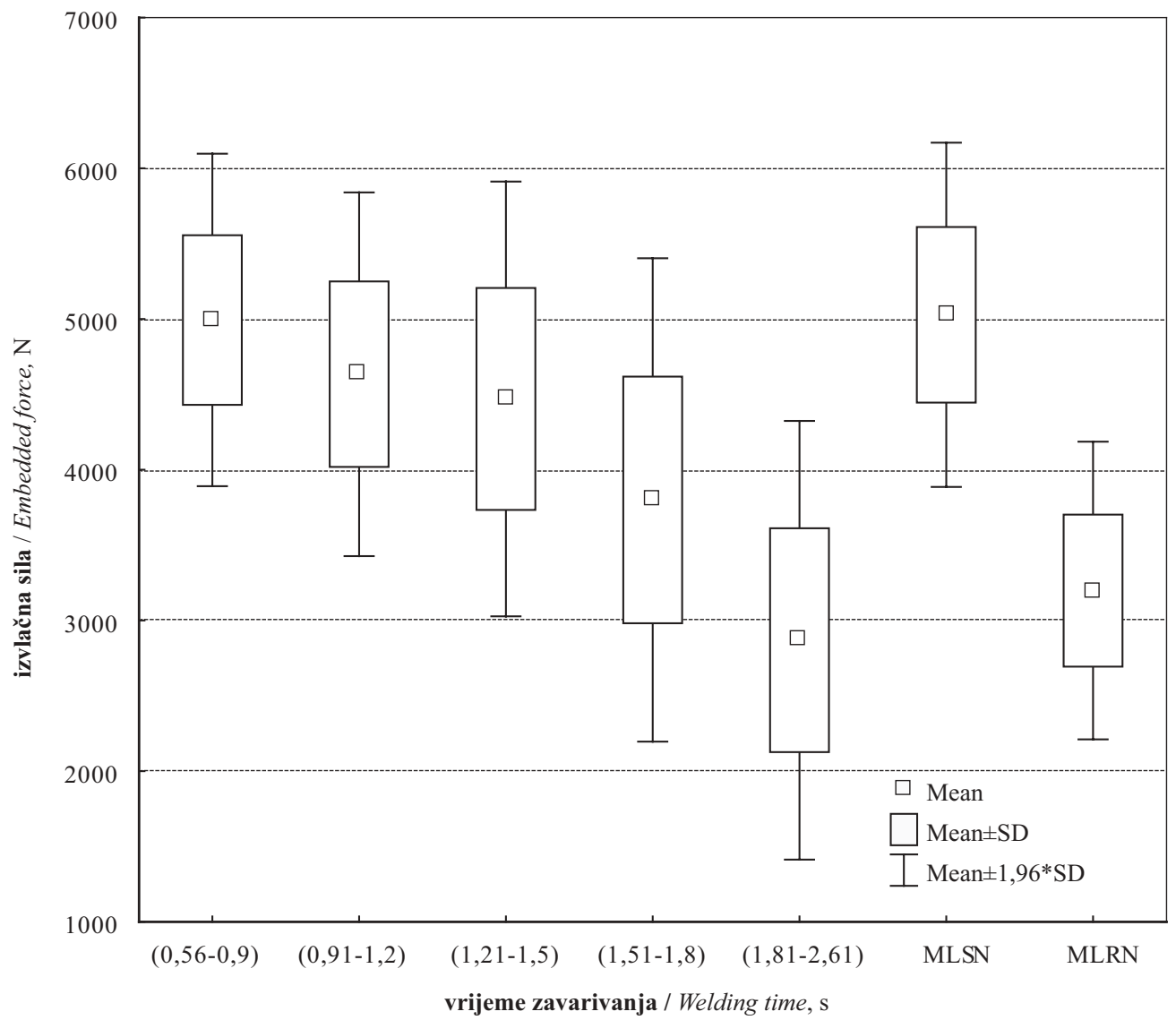

Slika 4. Ovisnost izvlačne sile o vremenskom intervalu zavarivanja te vrijednosti izvlačnih sila za kontrolne uzorke

Figure 4 Dependence of the dowel embedded force on time intervals of welding, and values of the dowel embedded force for controlled samples

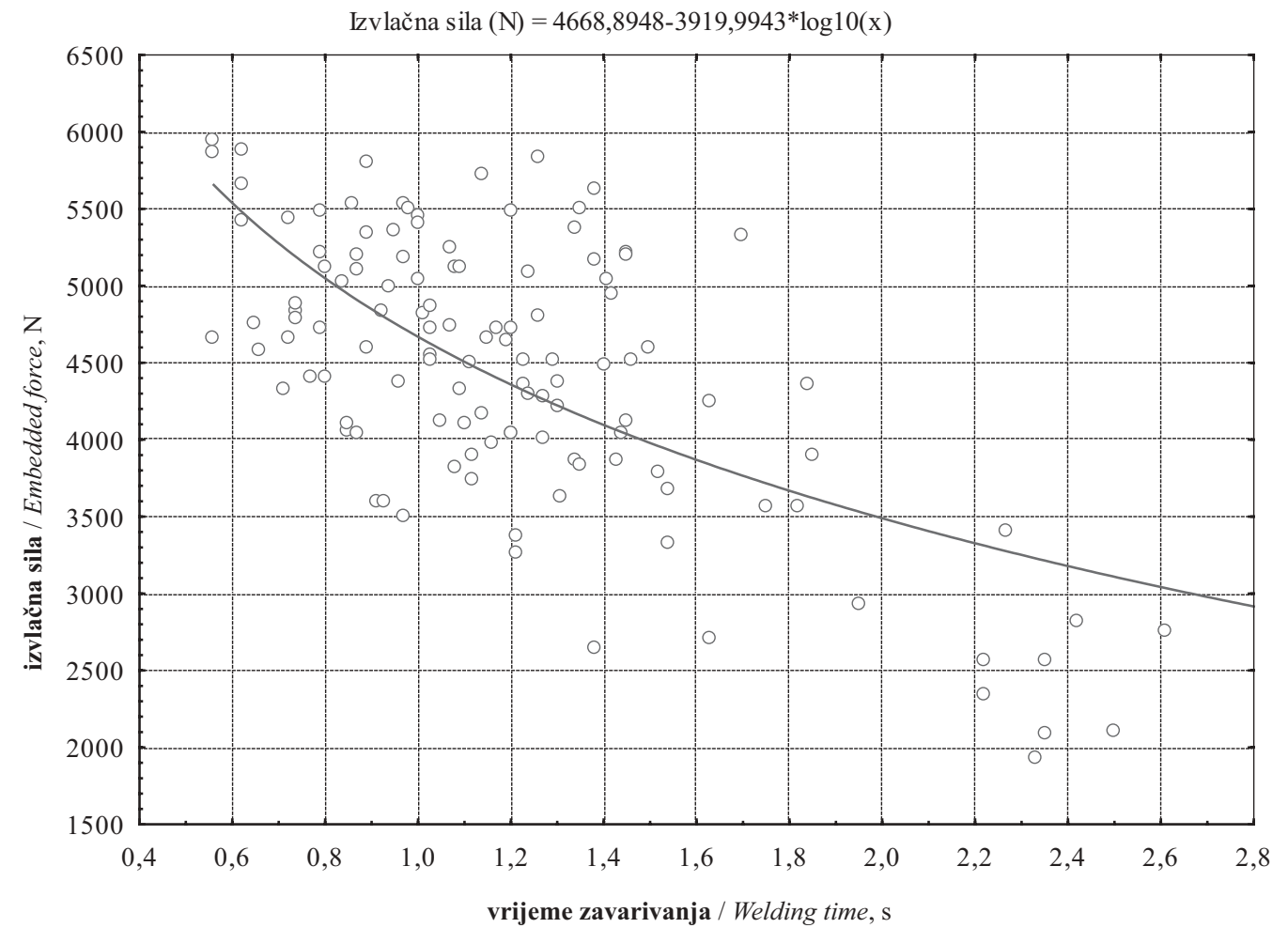

Slika 5. Usporedba izvlačnih sila i vremena zavarivanja

Figure 5 Comparison of embedded force and welding time 


\section{ZAKLJUČAK 4 CONCLUSION}

Ravno nažlijebljeni moždanici mogu se uspješno zavariti metodom rotacijskog zavarivanja za podlogu od bukovine u smjeru okomitome na drvna vlakanca (radijalno-tangentni presjek). Dobivene vrijednosti izvlačne sile odnosno čvrstoće zavarenog spoja mogu se uspoređivati sa čvrstoćama lijepljenog spoja.

Iz rezultata istraživanja vidljivo je smanjenje izvlačne sile odnosno čvrstoće spoja s produljenjem trajanja zavarivanja $(y=4668,9-3920,0 \cdot \log 10(x))$. S obzirom na to da je u vremenskom intervalu od 0,56 do $0,9 \mathrm{~s}$ izvlačna sila najveća, proizlazi da je to optimalan interval zavarivanja. Ako se utjecaj vremena zavarivanja promatra uz pomoć vremenskih intervala, tada je prihvatljivo vrijeme zavarivanja ravno nažlijebljenog moždanika do $1,5 \mathrm{~s}$ jer u tom vremenu nema statistički značajnog smanjenja izvlačne sile. Frekvencija vrtnje pritom je iznosila $1520 \mathrm{okr} . / \mathrm{min}$, dubina zavarivanja $20 \mathrm{~mm}$, a zador $2,02 \mathrm{~mm}$, jer ako se ti parametri mijenjaju, potrebno je odabrati drugačije vrijeme zavarivanja.

Zador ravno nažlijebljenog moždanika pri lijepljenju od $0,13 \mathrm{~mm}$ je premalen i utječe na statistički značajno smanjenje izvlačne sile u usporedbi s lijepljenjem spiralo nažlijebljenog moždanika sa zadorom od $0,42 \mathrm{~mm}$.

\section{LITERATURA 5 REFERENCES}

1. Ganne-Chedeille, C.; Pizzi, A.; Thomas, A.; Leban, J.M.; Bocquet, J.-F.; Despres, A.; Mansouri, H., 2005: Parameter interactions in two-block welding and the wood nail concept in wood dowel welding. J. Adhesion Sci. Technol., 19 (13-14): 1157 - 1174. doi: $10.1163 / 156856105774429037$

2. Ganne-Chedeville, C.; Properzi, M.; Leban, J. M.; Pizzi, A.; Pichelin, F., 2008: Interface microstructure development during wood welding. Proceedings of Final Conference in COSTE 34, Bonding of Timber, Enhancing bondline performance, Sopron, Hungary, 6-7 May 2008., 130-140.

3. Gliniorz, K. U.; Natterer, J., 2000: Holzschweißen Innovative Verbindungs-technologien in Holzbau, Symposium der ligna Plus/Weltmesse für die Forst- und Holzwirtschaft in Hannover, 9-18.

4. Gliniorz, K. U.; Mohr, S.; Natterer, J.; Navi, P., 2001: Wood Welding. Proceedings of the $1^{\text {st }}$ International Con- ference of the European Society for Wood Mechanics, Lausanne, Switzerland, 571-574.

5. Leban, J.-M.; Mansouri, H.R.; Omreni, P.; Pizzi, A., 2008: Dependence of dowel welding on rotation rate. Holz Roh Werkst. (66): 241-242.

6. Pizzi, A.; Properzi, M.; Leban, J.M.; Zanetti, M.; Pichelin, F., 2003: Mechanically - induced wood welding. Maderas. Cienca y tecnologia, 5 (2): 101-106.

7. Pizzi, A.; Leban, J.-M.; Kanazavwa, F., Properzi, M.; Pichelin, F., 2004: Wood dowel bonding by high-speed rotation welding. J. Adhesion Sci. Technol., 18 (11): 12631278. doi:10.1163/1568561041588192

8. Zoulalian, A.; Pizzi, A., 2007: Wood-dowel rotation welding - a heat - transfer model. J. Adhesion Sci. Technol., 21 (2): 97-108. doi:10.1163/156856107780437435

9. Župčić, I.; Bogner, A.; Grbac, I.; Hasan, M.; Hrovat, B., 2009: New findings in wood-welding research. Proceedings of International conference: Wood is good - new materials, quality and design of products: University of Zagreb, Faculty of Forestry, INNOVAWOOD, Zagreb, October $16^{\text {th }} 2009,77-83$.

10. Župčić, I.; Mihulja, G.; Govorčn, S.; Bogner, A.; Grbac, I., 2009: Zavarivanje termički modificirane grabovine, Drvna industrija, 60 (3): 161-166.

11. Župčić, I., 2010: Čimbenici koji utječu na spajanje bukovih tokarenih elemenata tehnikom zavarivanja. Sveučilište u Zagrebu, Šumarski fakultet, Disertacija, 1-237.

12. Župčić, I.; Bogner, A.; Grbac, I.; Lozančić. I., 2010: New insigts into rotation welding of beech wood. Proceedings of International conference: Wood is good - transferof knowledge in practice as a way out of the crisis: University of Zagreb, Faculty of Forestry, INNOVAWOOD, Zagreb, October $15^{\text {th }} 2010,147-152$.

13. *** HRN ISO 3130 : 1999. (hrvatska norma za određivanje sadržaja vode za ispitivanje fizikalnih i mehaničkih svojstava drva).

14. *** HRN ISO 3131 : 1999. (hrvatska norma za određivanje gustoće drva za ispitivanje fizikalnih i mehaničkih svojstava drva).

\section{Corresponding address:}

Assis. IVICA ŽUPČIĆ, Ph.D.

Department of Furniture and Wood Products

Faculty of Forestry

University of Zagreb

Svetošimunska 25, p.p. 422

HR-10002 Zagreb, CROATIA

e-mail: izupcic@sumfak.hr 